\title{
The State of Law and the Creation of a Human Rights Culture
}

\author{
Hoang Thi Kim Que
}

\section{The Development of the State of Law as an Idea and a Doctrine}

The state of law as an idea, doctrine, theory and reality has been through a long process of creation and development in the history of mankind. ${ }^{1}$ Today, theories about the state of law have been adjusted, amended and improved to be more adaptable to the current political, legal and social reality of the world. In both theory and practice, the state of law is witnessing a development combined with inheritance, addition and amendment. This all the more confirms the universal and particular values of the state of law on a global scale.

In ancient times only the fundamental components of the state of law were discussed such as the supremacy of the law, the power of the law over individuals, moral institutions and issues and to some extent even the separation of powers. In in early-modern times, the idea and doctrine of the state of law took a greater and further leap into the dialectics between the different elements of political systems, such as the state of law, civil society, human rights and legal measures to defend them, the separation of powers. Later, constitutionalism, legal procedures and legal systems are formed with the aim of protecting personal rights, freedom, and social security.

\footnotetext{
${ }^{1}$ Nguyen Xuan Tung (2016), Đẩy mạnh xây dựng Nhà nước pháp quyền XHCN Việt Nam dưới ánh sáng đại hội Đảng lần thú XI. http://moj.gov.vn/ct/tintuc/Pages/nghien-cuu-trao-doi.aspx?ItemID=4376.
} 
The theory as well as practice of the state of law in recent decades has been adjusted and become more and more extensive in terms of its contents, such as the state policies and responsibilities in protecting the security and safety of every individual in economic, political, social and cultural areas. A quick look at the constitutions throughout the history of mankind and especially at contemporary ones indicates this tendency, as coeval constitutions have extended their regulations on human rights and various socio-economic policies pursued by the nations. There are many similarities and differences between the ideas about the state of law from nation to nation and region and region, and this situation is best reflected in the reality of the state of law today. The realities of societies are introducing more issues to be studied and explained from the angle of state of law theory. There are more and more challenges to be coped with by nations, regions and the entire human race, such as human rights and national sovereignty, the role of civil society in developing policies and law; the interrelation between national and international laws; anti-terrorism; law and justice, morality, etc. These are emergent issues in reality but in theory they need further investigations.

The origins of the state of law as an idea and doctrine date back to ancient history, and since then both have been constantly enhanced and improved. The state of law as a social value shows its relevance in ideas, theories and reality. When the democratic revolutions in capitalist countries break out, these important values, especially in the West, are inherited from ancient states of law and transformed into a doctrine of state of law. The state of law's core elements are manifested in political and legal doctrines of various Westerns thinkers throughout history from antiquity to the modern period. Most notable among these doctrines are the ideas of separation and management of state power, human intrinsic rights and the relations between state of law and civil society. The doctrine of the state of law is diverse in its contents and applied at different levels and scales in countries around the world, in which genuine doctrines are diverse. As mankind's history is constantly on the move, social theories in general and state of law theories in particular have to be adjusted and reformed. Inheritance and improvement of previous versions are basic features of the idea, doctrine and reality of the state of law around the world.

In terms of its ideological basis, the context that gives rise to the idea of the state of law in the West is different from that in the East, as Greek and Roman democracies are to some extent more sophisticated because they are based on 
philosophical thinking and the pursuit of an objective and rational mindset, and are at relatively higher stages of development. Thus Western ideas are different from their Eastern counterparts, according to which the law is not only a ruling instrument but a social value which regulates social relations and a common principle to be adhered to by the state. Many fundamental issues of state of law are thoroughly dissected in the works of prominent ancient Greek and Roman thinkers, especially the ideas on innate human rights and the state's responsibility to protect these.

In Western ancient conceptions as a whole, the law has an important value and position and is the art of the good and the equitable "Jus est ars boni et aegui“. This idea also points to the connection between the law and morality, i.e. moral basis, functions and values of the law and, vice versa, the law as an instrument to protect and ensure social morality. In his Philosophy of Right, Hegel also considered legal issues in relation to moral and ethical issues.

Ancient Western ideas on the state of law include such basic elements as the role of the law in protecting human intrinsic rights, settlement of civil disputes, supremacy of the law, adherence to the law as a responsibility of every individual; the correlation between human law and natural law, ethics and justice; and the proper organization of a government that allows for the avoidance of abuse and autocracy. Basic ideas on the state of law are articulated in such works of prominent and well-known thinkers as Aristotle, Plato, Solon, Socrates and Cicero. Most notable of which is the state of law idea of the great ancient thinker Aristotle that emphasizes the domination of the law and separation of powers. According to Cicero, Socrates and Plato, it is necessary to legitimize the power of the law over individuals, even over the state, and to respect and observe the law is to respect rationality, justice and universal intellect, without going astray. ${ }^{2}$

Ancient ideas on the state of law are inherited and promoted by bourgeois thinkers. The introduction of the state of law doctrine is associated with the names of great thinkers such as John Locke, Montesquieu, Rousseau, Kant and Hegel, etc. The bourgeois doctrine of the state of law include such basic components as the protection of human rights and freedom by the law, the supremacy of the law as a general principle regulating state affairs, equality be-

\footnotetext{
${ }^{2}$ Le Doan Ta (1994), 55.
} 
tween the state and individuals, civil sovereignty, and the separation and control of state power, etc.

The renowned French thinker Montesquieu in his work "The Spirit of the Law" introduces the theory of separation and control of state power - one of the basic conditions to protect human intrinsic rights and freedom. In philosophical terms, German thinkers have developed more profound ideas of the state of law and civil society. According to Immanuel Kant, the state consists of law-abiding and legally-conscious citizens, and the state itself has to abide by the law. Any slight departure from the separation of powers would lead to an authoritarian state. Hegel in his Philosophy of Right defines the structure of a state of law as composed by civil society and a state of law legal order.

Components of a state of law are also indicated in Marxist-Leninist thinking on state and law. On freedom and the state's role and duty in protecting and ensuring human liberty, Karl Marx writes: "the development of individual liberty precedes the development of communal liberty." Marx wrote to American President Abraham Lincoln in which he highly appreciated the American Declaration of Independence, valorizing human rights and the role of republican and democratic governments in protecting these rights.

The question has arisen: is the state of law present in Eastern ideas, and what are the similarities and differences between Eastern and Western ideas and doctrines on the state of law? In recent decades when the human race has witnessed a more comprehensive understanding of the state of law and especially of its reality, a common assumption is being formed that the state of law also exists in various schools of thought, policies and legal systems of Eastern states. In particular, moral and humanistic values are among the core components of Eastern states of law.

Looking back at the Eastern political-legal thinking, the concept of the state of law exists for example in different viewpoints on the law, state and morality of ethical and legal principles. Basic as they are, elements of the state of law are manifested in the works of Chinese thinkers such as Confucius, Mencius, Xun Kuang, Han Fei and Vietnamese feudal politicians and thinkers such as Nguyen Trai and Le Thanh Tong. We also recognize many similarities in moral and legal conceptions of both Eastern and Western thinkers such as Confucius, Mencius, Han Fei, Aristotle, Montesquieu, Hegel and Kant.

${ }^{3}$ Marx/Engels (1980), 569. 
Mutual recognition between Eastern and Western values and ideas in the construction of the state of law can also be regarded as one of the dynamics in the theory and practice of contemporary political and legal systems. Confucian ideas on morality, though still limited and far from being legal ethics if judged from the perspective of human rights and liberty, contain many values. Confucian legal ideas are based on humanistic tenets and compassion. Similar ideas are prevalent in contemporary constitutional theory. Confucius' anthropological ideas on the law are clearly embedded in his doctrine of the people and doctrine of the mean, which reflects his humanistic principles. ${ }^{4}$

A common juncture of all Eastern and Western schools of thought throughout history is the desire for an ideal and virtuous state and society in which everyone enjoys happiness and social stability and justice. Whether from a Western or Eastern perspective, the state of law has to cope with such legal and moral issues, especially in contemporary society, as capital punishment, the application of biological and medical technologies, and criminalization and decriminalization, etc.

The individual plays an important role throughout Eastern ideas and doctrines but is viewed divergently depending on the human's role in community, family, society and state. Therefore, the character of relations such as those between the individual and the state and the society are interpreted differently in Eastern and Western ideas during the ancient, medieval and early-modern periods. Today, in the context of globalization and the worldwide development towards a state of law and market economy, in legal and social theories and realities there have been fundamental changes in the relations between the state and individuals, the state and society, and between individuals and collective institutions, including the sphere of family. The state of law has broad implications, but its core principles are the protection and promotion of human rights, freedom, interests and an all-rounded development based on moral and legal values. This is the main similarity between Eastern and Western ideas on the state of law.

The similarity between Eastern and Western conceptions of an ideal state, commonly known as the "state of law", is nothing but respect for people themselves and is agreed by politicians and scholars. Here I would like to cite the

\footnotetext{
${ }^{4}$ Du Vinh Căn (2008), 335.
} 
words of the British Secretary of State for Justice during his visit to our university on September $11^{\text {th }} 2008$ :

"Let me quote one of the teachers from Asian ancient history. To the question, 'Is there one word that can serve as a principle of conduct for life?' Confucius replied, 'It is the word shu-reciprocity. Do not impose on others what you yourself do not desire (Doctrine of the Mean). Whether your tradition is eastern or western, ancient or modern, shu is an important principle for us all. The state of law can give effect to it and make it the foundation of a peaceful, prosperous and just society."

In Vietnam, before long President Ho Chi Minh introduced the idea of the state of law, especially as a part of the constitution, which includes important components such as the spirit of the law, independent jurisdiction, and relations between law and morality, between law and democracy and social justice. His ideas were realized in the Declaration of Independence dated September $2^{\text {nd }} 1945$, the first Constitution of Vietnam. Ho Chi Minh adopted the ideas of human rights by citing the statement of Thomas Jefferson - a renowned statesman who participated in the American struggle for independence:

"All men are created equal. They are endowed by their Creator with certain inalienable rights; among them are Life, Liberty, and the pursuit of Happiness." And he further added: "In a broader sense, this means: All the peoples on the earth are equal from birth, all the peoples have a right to live, to be happy and free."

The 2013 Constitution inherits Ho Chi Minh's basic points on the state of law, including the idea of human rights, civil sovereignty and state's responsibilities with respect to its people.

Similarities and Differences, Universality and Particularity and the Current Development of the State of Law Around the World

Conception of the State of Law

This issue is no longer new but needs further discussions, as the ideas, theories and practical affairs of different nations and regions regarding the state of law

\footnotetext{
${ }^{5}$ Speech by British Secretary of State of Justice Jack Straw at the Department of Law, Vietnam National University, Hanoi, 2008. http://www.justice.gov.uk/news/sp120908a.htm

${ }^{6}$ Hồ Chí Minh (1995), 1.
} 
share both similarities and differences, expressing both universal and particular aspects of the state of law. This is especially the case in state policies and legal regulations and in citizens' awareness and behaviors. For example, the viewpoints and policies on social security and state responsibilities vary quite regularly from country to country in the world.

\section{On the Concept of the State of Law in the World}

The widely used term in the world is currently "state of law" or "Rechtsstaat". The state of law has quite a long history but was officially introduced in the $19^{\text {th }}$ century and became an increasingly popular term in the second half of the $20^{\text {th }}$ and early $21^{\text {st }}$ century. ${ }^{7}$ It originally came into being in Germany (Rechtsstaat) and later spread to France (État de droit) and other European countries and other continents and is now widely referred to in English as "state of law". In my opinion, this issue needs further discussions as it is not merely a concept but reflects similar and different viewpoints on the state of law across nations and regions.

In the German term "Rechtsstaat". Recht means law while Staat means State. In French there is "État de droit" and English there is "state of law". The United States used to retain a corresponding concept "due process of law" which was introduced by the $14^{\text {th }}$ Amendment (1868). This term expanded to include not only the government's responsibility to maintain procedural due process, such as organizing proper court cases, but also substantive due process.

Today, the term "state of law" in English is generally favored. Sometimes, to adapt to other interpretations of nations of "state of law", other usages have to be included such as "the state governed by the state of law" and "the lawgoverned state". ${ }^{8}$ Even in Vietnamese, nhà nước pháp quyền (state of law) is actually opted for instead of nhà nước pháp luật (legal state) and nhà nước pháp trị (state by law). An interesting point that can be drawn from this is that in another version of the Anglo-American interpretation, "the state of law" indicates "state of law" without referring to the word "state", whereas in European and Russian terms the "state" is included. Despite different interpretations and angles pursued by these concepts, they share a common point of view that "state of law" implies the supremacy of the law by which the state has to

\footnotetext{
${ }^{7}$ See Thai Vinh Thang (2009), 63-74.

${ }^{8}$ See Nguyen Si Dung (2004).
} 
abide (i.e. state power is limited), as it is in charge of protecting human rights and freedom; and everyone is equal before the law.

"The state of law" encompasses a broader meaning which goes beyond "the state". Of course, what leads to the usage of "the state of law" instead of other German, French and Russian terms is not yet fully answered and results from the different social, cultural, political and moral systems of aforementioned countries in both the past and present. The state of law is necessarily associated with "the state of law" instead of "the rule by law". This is one of the basic and important principles in the making and implementation of policies and laws and in interpersonal relations. This is especially true for countries witnessing a transition from a top-down management system to a more civilized system based on the principles of equality, justice, transparence and legal and constitutional supremacy.

The term "pháp quyền" in Vietnamese also has important and relevant associations with the humanistic nature of state of law. It is closely related to Western and human conceptions of "pháp luật" - "right” today. Pháp luật means "droit" in French, "right/law" in English, "Recht" in German, "dirito" in Italian and generally refers to the proper conduct, fairness, justice, impartiality, precision, truth, appropriateness and also rights. The original term "jus” springs from "justitia” - judgments, jurisdiction, justice, as law is a science and art of what is good and just and is always justice and goodness - the law is expected, rational and meaningful. Justice has long been considered an advanced legal aspect of human society as said by the ancient Latin maxim: Jus est ars boni aequi: law is the art of benevolence and justice.

\section{In Search of a Definition of State of Law}

The concept of the state of law contains a broad range of meanings and its components and basic features are qualitatively different from that of nonstates of law. Thus, there are various definitions of this term, which share both similarities and differences. What distinguishes these definitions from one another is that each tends to focus on its preferred and prioritized aspects of the state of law. Accordingly, while some relate state of law to human rights, others concentrate on the separation and control of power and the limitation of state power; supremacy of the law, democracy, and independent jurisdiction, etc. Each definition is both relevant and important in the clarification of the state of law. 
According to Roman Herzog, "state of law implies a state that does not interfere with the affairs of individuals and only exists to benefit its citizens." Renowned English lawyer, A.V. Dicey, in his Introduction to the Study of the Law of the Constitution (1915) explicates the state of law by using three characteristics: the law is supreme and the state is not allowed to abuse it in any case; everyone is equal before the law; and the state of law means constitutional law. ${ }^{10}$ German legal and political scholars in their monograph on the state of law evaluate and introduce this concept by elucidating its main features: the state of law is established and run on the basis of moral values, justice and integrity, and state power is limited by the law; the state of law ensures human rights; the core essence of a state of law is that the state functions to benefit its citizens, etc. ${ }^{11}$ By studying and referencing theoretical and practical examples, we attempt to define state of law as follows:

State of law is a political system that is organized and maintained on the separation and control of state power, limiting state power by means of laws as the ultimate power according to justice, integrity and the assurance of human interests; the state is responsible for respecting and devising necessary legal measures to safeguard and defend human rights and freedom from any violation, and for democratizing social activities, and its relations with citizens are based on equality and mutual accountability. Regarding its basic and notable features (or principles), there are differences in the theorizing the state of law. These features also indicate the level of development of each state of law and civil society. Generally speaking, the state of law can be said to possess the following features/principles that also contribute to its identification.

The state of law is responsible for ensuring the supreme position of the Constitution and law in social and state affairs. It is the law that dominates a state of law and not individuals. This is ensured by the fact that the power of the law is created, respected and followed. When the law is supreme, regulations are legitimate, legally and constitutionally created. It is not only the state law that is supreme but also justice, because the law serves humanity and justice, revealing its moral aspects. According the German author Josef Thesing,

\footnotetext{
${ }^{9}$ Thesing (1997), 36-47.

${ }^{10}$ See Dicey (1915), 120.

11 Thesing (1997); and ibid essays of Robber, 48-85; Beson/Jasper, 180-200; Martin/Kriele, 223-250; Herzog/Thesing, 9-17.
} 
the state of law has to base on "the supremacy of the law and ethical concepts of justice." 12

The state of law is responsible for respecting, protecting and ensuring the rights and freedom of humans and citizens. By and large: "human rights imply the intrinsic, natural and objective demands and interests of humans which are recognized and inscribed in national laws and international legal treaties". ${ }^{13}$ Former UN General Secretary Kofi Annan once declared:

"Human rights are common to every culture and a friend of every nation." 4

Human and civil rights are the basis and purpose and also criteria for the evaluation of all state bodies and public servants. The state is charged with protecting and ensuring the rights and freedom of humans and citizens, identifying and providing necessary conditions in political, economic, cultural, social and technological fields to maintain these rights in practice. The state is obliged to abide by constitutional principles on the rights and freedom of humans and citizens, and is prohibited from abusing and misusing the law to restrict, distort and manipulate the nature of these rights.

The state is organized and maintained on the separation of state power between the legislative, executive and judicial branches which are clearly defined in the Constitution and law. Compliance with the law is required of all individuals and organizations, including the state. The state is responsible for compensating material and spiritual loss of its citizens and organizations caused by unconstitutional decisions and acts. Judiciary bodies have to be independent and capable of protecting the rights, freedom and legitimate interests of individuals and citizens, and have to decide on and resolve disputes according to the law, integrity and justice.

\section{Democracy, Civil Society and Sustainable Development}

The state of law is a democratic state, and all of its policies and operations are transparent and public so that citizens and social organizations can contribute their opinion and feedback. The state of law can only function and exist in conjunction with a well-developed civil society. In return, civil society and its

12 Thesing (1997), 55.

${ }^{13}$ Nguyen Dang Long/Vu Cong Giao/La Khanh Tung (2009), 209.

${ }^{14}$ Statement of UN General Secretary Kofi Annan on International Human rights day in 1977, paragraph 3. 
members can only exist and function when a state of law is ensured. The law within a state of law must ensure such qualities as justice, humanity, equality, the protection of human freedom and interests, harmony of interest between individuals, state, community and society, and compatibility between national law and international law. What distinguishes contemporary conceptions of state of law is the increasing expansion of its contents instead of a mere focus on forms as in previous interpretations. In the past the state of law is primarily understood and explained in terms of its forms, i.e. compliance with the law, binding regulations towards the state, limited state power, and even power control, although they are its basic, prominent and innate characteristics. In contemporary society, the contents of state of law become more vital, namely the responsibility of states in protecting, ensuring and promoting human rights, freedom and interests, maintaining justice and democracy, and promoting the economy, culture, social security and welfare and living conditions. The state of law has a new role as a social servant and its permanent responsibility as a modern state is to "facilitate the authentic life of everyone as a human being." 15

\section{Creation of a Human Rights Culture and Human Rights Education. A Prerequisite for the Construction of a State of Law}

Human rights culture is one of the cultural forms in general and at the same time the foundation of every other cultural form in contemporary life. The category of culture has a broad range of meanings and is not easy to define. ${ }^{16}$ Currently there are around 400-500 definitions of culture. This concept encompasses material and spiritual values formed and created by human activities, which are transferred back and forth between generations and communities, creating particular national identities along with universal elements.

Legal culture is the system of material and spiritual values within the hemisphere of the law and manifests in human consciousness, ideas, conventions, legal principles and behaviors. The most culturally relevant aspect of juridical acts is reflected in legitimate judgments that are based on prudence and justice

\footnotetext{
${ }^{15}$ Ysumirrô/Takahara/Bikishimoto (1994), 30.

${ }^{16}$ See Central Committee for Ideology and Culture (2001), 222.
} 
and the protection of human rights, freedom and legitimate interests. ${ }^{17} \mathrm{Hu}-$ manity is the core element of culture. Human rights culture refers to the understanding and respect, recognition, protection, assurance and promotion of human rights; human rights and freedom are the highest values protected and guaranteed by the system of social, political and legal institutions. Human rights culture is the center of political-legal-moral aspects of modern society. Human rights today have become universal values and are said to constitute part of human culture. Without human rights, it is impossible to make full evaluation of the complicated formulation of political, social, economic, legal and cultural relations.

Authentic culture always takes humans as its purpose, objective and ultimate aim. The state is thus responsible for acknowledging and respecting human rights and its citizens' rights, freedom and legitimate interests. Humanity is served by the state and is never mechanically understood as just a tool. Culture goes hand in hand with sacred values of the spiritual life which together make up a human being. State of law is constitutional, legitimate, reasonable and effective, a state that is organized and maintained based on moral principles, a fair State with its ultimate aim to ensure safety and development for all.

The creation of a human rights culture is prerequisite for the foundation of a state of law. Human rights culture is reflected in the policies and laws, in the operation of public organs and services and in interpersonal conduct. In particular, it is expressed in the collection and making of legal documents and law enforcement; in the system of protective measures to guard human rights. The most relevant manifestation of human rights culture is in the spirit and principles of a democratic constitution, in which the state of law is recognized, respected, protected, ensured and cited by first of all public sectors and officials who are most likely to make unconstitutional acts. ${ }^{18}$

Human rights culture is a multi-dimensional category and a complex formulation consisting of different components, layers and degrees of manifestation. Overall, it is a combination of basic elements such as knowledge and understanding of human rights, protective measures for human rights, respect for human rights and recognition of moral norms and values; and skills in protecting human rights and the supremacy of law and constitution. The na-

\footnotetext{
${ }^{17}$ See Hoang Thi Kim Que/Ngo Huy Cuong (2011).

${ }^{18}$ Nguyen Dang Dung (2012), 5.
} 
ture of human rights culture is marked by this formula: knowledge-respectpractice (recognition, compliance, use) of human rights and freedom. This is especially true for public servants, who have a higher probability of violating the constitution compared to other individuals and citizens. The indicators of a developed human rights culture and a constitutional culture are acknowledgment, admiration, protection and assurance of the rights and freedom of citizens in both attitudes and behavior.

\section{Human Rights Education}

There are both long-term and immediate tasks to in order to create a human rights culture. First of all, it is necessary to establish effective human rights education for the entire society, especially for public staff who are making legal decisions that affect these rights. The human rights education is a common statement of this era:

"the more a human is cognizant of his own rights, the more he respects the rights of others and further contributes to peaceful coexistence. Only when the people are educated about human rights can we hope to prevent their violation and reduce conflicts. ${ }^{\prime \prime} 19$

The human rights education is aimed at providing everyone since his childhood with necessary knowledge on human rights according to national and international law and on important values such as democracy, equality, justice, freedom, responsibility, tolerance and accountability to oneself and to others. Compassion, lenience and care for others are traditional ethical values that need to be retained and given their right position in the new system of moral values.

At the international level, since 1994 the United Nations has been proposing the decade of human rights education on a global scale. The sacred mission and spirit of the Global Strategy on Human Rights Education are manifested in the acquisition of necessary knowledge and understanding of human rights so that each individual is aware of and practice their own rights while respecting and protecting the rights of others. In this way human beings become closer and more tolerant towards each other regardless of any distance and are more likely to live in peaceful development.

${ }^{19}$ Statement of UN General Secretary Kofi Annan on International Human rights day, December $10^{\text {th }} 2000$; UN Press release, 10 February 2000. 
Human rights education is a purposeful and oriented task that aims to provide citizens and public officials with necessary know-how on human rights and defensive methods so that they can practice and protect their own rights while valuing others' according to national and international laws on human rights. ${ }^{20}$

Human and civil rights have become basic indicators of the development of each state in terms of its social system, respect for humanity, democracy and civilization. Human rights education needs to be widely applied. "Prioritized" targets of this activity are public staff and servants and especially law enforcers who are endowed with legal authority and at the same time responsibility to ensure the maintenance of human and civil rights.

Humanity holds the highest values, and any discussion about humanity and human rights necessarily has to relate to a humanistic aspect, namely morality. Thus, human rights education can be only be efficient and genuine in combination with moral education. Moral education, human rights education and legal education have to be in line with economic and cultural education, and the training of living skills and law application. Without basic economic and cultural conditions and proper cultural conduct, it is impossible to maintain and protect human rights, except in mere slogans. Human rights education should constitute an important part in developing a just society in which basic human rights are valorized and respected.

Human rights education and legal education not only prevent the violation of the law but also promote in everyone a sense of respect for human values, for the rights and freedom of oneself and everyone else. The teaching of human rights must take in account the dissection of basic human values and the importance of respect for human rights; the awareness of human values, respect for others' rights and interests, and understanding of justice, freedom and personal responsibility towards one's community and society.

The idea of human rights in connection with freedom and national independence has been most vividly indicated and inscribed in Vietnam's constitutions up to now, especially the 2013 Constitution. Vietnam has made great achievements in the protection and assurance of human rights. The construction of a human rights culture and human rights education are especially important in realizing the 2013 Constitution by introducing constitutional prin-

\footnotetext{
${ }^{20}$ Hoang Thi Kim Que (2006).
} 
ciples into daily life, in particular by actualizing regulations on human rights and the basic civil rights and duties.

\section{References}

Central Committee for Ideology and Culture. Ministry of Culture and Information (ed.) (2001): Culture and Business. Hanoi.

Dicey, Albert Venn (1915): Introduction to the Study of the Law of the Constitution. London.

Du Vinh Căn (2008): Confucius Legal Ideas (Tư tưởng pháp luật Nho gia). Hanoi.

Hồ Chí Minh (1995): Collected works. Volume Four. Hanoi.

Hoang Thi Kim Que (2006): Human Rights and Human Rights Education in Vietnam Today (Quyền con người và giáo dục quyền con người ở Việt Nam hiện nay). In: Journal of Science, VNU, Special Issue on EconomicsLaw, issue 3/2006.

Hoang Thi Kim Que/Ngo Huy Cuong (eds.) (2011): Legal Culture - the Basic Theoretical and Applied Issues (Văn hóa pháp luật - những vấn đề lý luận cơ bản và ứng dụng chuyên ngành). Hanoi.

Le Doan Ta (ed.) (1994): Essays on Historical Philosophy. Second volume. Hanoi.

Marx, Karl/Engels, Friedrich (1980): Selected Works. Volume 1. Truth Publisher. Hanoi.

Nguyen Dang Dung (2012): The Violation of the Constitution and Forms of Unconstitutional Behaviors (Vi phạm Hiến pháp và các loại hình vi phạm Hiến pháp). In: Journal of Legislative Studies, 9 (216).

Nguyen Dang Long/Vu Cong Giao/La Khanh Tung (eds.) (2009): Textbook on Human Rights Theory and Law (Giáo trình Lý luận và pháp luật về quyền con người). Hanoi.

Nguyen Si Dung (2004): The Origin of Rule of Law (Cội nguồn pháp quyền). Tia sang magazine, 2004, 7, and Youth newspaper dated 16 August 2004. Nguyen Xuan Tung (2016): Promote the Construction of Vietnamese Socialist Rule of Law under the Orientation of the $11^{\text {th }}$ Party Congress (Đẩy mạnh xây dựng Nhà nước pháp quyền XHCN Việt Nam dưới ánh sáng đại hội 
Đảng lần thứ XI). http://moj.gov.vn/ct/tintuc/Pages/nghien-cuu-traodoi.aspx? ItemID=4376.

Speech by British Secretary of State of Justice Jack Straw at the Department of Law, Vietnam National University, Hanoi, 2008. http://www.justice.gov.uk/news/sp120908a.htm.

Statement of UN General Secretary Kofi Annan on International Human rights day in 1977, paragraph 3.

Statement of UN General Secretary Kofi Annan on International Human rights day, 10 December 2000; UN Press release, 10 February 2000.

Thai Vinh Thang (2009): Reformation and Amendment of the 1992 Constitution towards the Development of a Socialist State of Law and International Integration (Sửa đổi, bổ sung hiến pháp năm 1992 đáp úng yêu cầu xây dựng nhà nước pháp quyền xã hội chủ nghĩa và hội nhập quốc tế). Essay from Hanoi Law University. The Vietnamese Laws in the Process of International Integration and Sustainable Development (Pháp luật Việt Nam trong tiến trình hội nhập quốc tế và phát triển bền vững). Hanoi.

Thesing, Josef (ed.) (1997): The Rule of Law. Sankt Augustin.

Ysumirrô, O./Takahara, M./Bikishimoto, S. (1994): Japan's Politics and Economy (Chính trị và kinh tế Nhật Bản). Hanoi. 